\title{
PENGGANTIAN SEBAGIAN JAGUNG DENGAN TEPUNG BATANG PISANG GOROHO ( Musa acuminata, sp) DALAM RANSUM TERHADAP PERFORMANS BROILER
}

\author{
Melinda O. Manalip, M. Najoan*, M. R. Imbar, dan Y. H. S. Kowel \\ Fakultas Peternakan Universitas Sam Ratulangi Manado, 951115
}

\begin{abstract}
ABSTRAK
Suatu penelitian yang bertujuan untuk melihatpengaruh penggantian sebagian jagung dengan tepung batang pisang goroho (Musa acuminata, SP) dalam ransum terhadap performansbroiler, telah dilaksanakan dikandang unggas Fakultas Peternakan Unsrat Manado .dengan menggunakan 60 ekor broiler CP 707 umur 3 minggu. Metode penelitian yang digunakan adalah Rancangan Acak Lengkap yang terdiri dari 4 perlakuan dan 5 ulangan. Perlakuan terdiri dari R0 : tanpa penggantian tepung batang pisang goroho, R1 : Penggantian dengan 5\% tepung batang pisang goroho, R2 : Penggantian dengan $10 \%$ tepung batang pisang goroho, R3 : Penggantian dengan $15 \%$ tepung batang pisang goroho. Variabel yang diukur yaitu konsumsi ransum, pertambahan berat badan dan konversi ransum

Hasil analisis keragaman menunjukan bahwa pengaruh perlakuan memberikan pengaruh yang tidak nyata ( P> 0,05) terhadap konsumsi ransum , sedangkan Pertambahan bobot badan dan konversi ransum memberikan pengaruh yang berbeda nyata $(\mathrm{P}<0,05)$. Hasil Uji Tukey menunjukan bahwa pertambahan bobot badan $\mathrm{R}_{0}$ berbedatidak nyata $(\mathrm{P}>$ 0,05) dengan perlakuan $\mathrm{R}_{1}$, tetapi $\mathrm{R}_{0}$ berbeda nyata $(\mathrm{P}<0,05)$ dengan perlakuan $\mathrm{R}_{2}$ dan $\mathrm{R}_{3}$ sedangkan Perlakuan $\mathrm{R}_{1}$ dengan $\mathrm{R}_{2}$ dan $\mathrm{R} 1$ dengan $\mathrm{R}_{3}$ menunjukkan
\end{abstract}

*Korespondensi (Corresponding author) Email : najoanmarie@yahoo.com pengaruh yang berbeda nyata $(\mathrm{P}<0,05)$. Uji Tukey terhadap konversi ransum menunjukan bahwa $\mathrm{R}_{3}$ berbeda nyata ( $\mathrm{P}<$ $0,05)$ lebih tinggi dibandingkan dengan $R_{0}$, $\mathrm{R}_{1}$ dan $\mathrm{R}_{2}$, sedangkan antara $\mathrm{R}_{0}$ dan $\mathrm{R}_{1}, \mathrm{R}_{2}$ dan $R_{3}$, berbeda tidak nyata $(P>0,05)$, dan perlakuan antara $R_{0}$ dan $R_{2}, R_{0}$ dan $R_{3}, R_{1}$ dengan $R_{2}, R_{1}$ dengan $R_{3}$, menunjukan perbedaan yang nyata $(\mathrm{P}<0,05)$

Berdasarkan hasil penelitian, dapat disimpulkan bahwa tepung batang pisang goroho (Musa acuminta, sp) dapat menggantikan sebagian jagung sampai 5\%dan memberikan performans broiler yang baik.

Kata kunci: Broiler, Batang pisang Goroho, performans broiler

\section{ABSTRACT}

A study was aimed to evaluated the effect of partial replacement of corn with goroho banana stem mealon broiler chicken performans. The study was conducted at Faculity of Animal Science, University of Sam Ratulangi Manado. Using sixty three weeks broiler CP 707. Research used a complete randomized design, consisting of 4 treatmenst and 5 replications, ie Ro : ration without goroho banana stem meal, R1 : 5\% corn meal replaced with goroho banana stem meal, R2 : $10 \%$ corn meal replaced with goroho banana stem meal, R3 : 15\% corn meal replaced with goroho banana stem meal . The variables which measured were : ration consumption, body weigth gain and ration conversion. The data were analyzed 
using analysis of variance ( Anova), and any significant differences were further test using Tukey test. The treatment was non significantly diference $(\mathrm{P}>0,05)$ on ration consumption, but significantly difference $(\mathrm{P}>0,05)$ on body weight gain and ration conversion.

The results of analysis of variance showed that the was non significantly difference $(\mathrm{P}>0.05)$ on ration consumption, while the addition of body weight and ration conversion were significantly difference ( $\mathrm{P}>0,05$ ). The Tukey test showed that the body weight gain of $R_{0}$ non significantly diference ( $P$ $>0,05$ ) to the treatment of $R_{1}$ however $R_{0}$ was significantly diference to $R_{2}$ and $R_{3}$, while the treatment of $R_{1}$ with $R_{2}$ and $R_{1}$ with $R_{3}$ showed significantly difference $(\mathrm{P}>0.05)$

Based on this study, it could be conduded the Goroho banana stem meal (musa acuminata, sp) could substitute a part of corn up to $5 \%$ which made a better performance for broiler chicken

Keywords : Broiler, Goroho banana steam meal, broiler performans

\section{PENDAHULUAN}

Peningkatan jumlah penduduk Indonesia dari tahun ke tahun berdampak pada peningkatan konsumsi produk peternakan (daging, telur, susu). Meningkatnya kesejahteraan dan tingkat kesadaran masyarakat akan pemenuhan gizi khususnya protein hewani juga turut meningkatkan angka permintaan produk peternakan. Daging banyak dimanfaatkan oleh masyarakat karena mempunyai rasa yang enak dan kandungan zat gizi yang tinggi. Broiler merupakan salah satu sumber daging yang paling banyak dimanfaatkan oleh masyarakat Indonesia.

Broiler adalah strain ayam hasil budidaya teknologi yang memiliki pertumbuhan cepat, konversi pakan yang baik dan dapat dipotong pada usia yang relatif muda (4-5) minggu sehingga sirkulasi pemeliharaannya lebih cepat dan efisien serta menghasilkan daging yang berkualitas baik. Broiler mempunyai peranan yang penting sebagai sumber protein hewani asal ternak karena merupakan salah satu penyumbang terbesar protein hewani. Broiler sangat efisien berproduksi karena didukung oleh sifat genetik dan faktor lingkungan meliputi manajemen dan pakan. Amrullah (2004) menyatakan bahwa potensi broiler cukup besar di Indonesia, yaitu mempunyai arti ekonomi yang cukup tinggi sebagai penghasil protein hewani.Keuntungan dari pemeliharaan broiler adalah menghasilkan daging dalam waktu yang relatif singkat, serta pemeliharaannya hanya membutuhkan lahan yang relatif sempit.

Jagung merupakan pakan sumber energi utama ternak unggas yang digunakan sekitar 45-55\% dalam ransum. Kebutuhan jagung pada ternak masih bersaing dengan manusia.Salah satu alternatif untuk mengatasi hal tersebut adalah memanfaatkan limbah pertanian seperti batang pisang. Batang pisang 
tersedia secara kontinu, mudah didapat, dan harganya relatif murah karena setelah ditanam pisang dipanen dan batangnya hanya dibuang begitu saja.

Mengatasi masalah ketersediaan pakan dengan menggunakan batang pisang telah banyak dilakukan pada ternak ruminansia, akan tetapi potensinya sebagai pakan nonruminansia (unggas) belum banyak digunakan. Salah satu jenis pisang lokal yang spesifik di daerah Sulawesi Utara adalah pisang goroho (Musa acuminate, $\mathrm{sp}$ ). Jenis pisang ini pemanfaatanya mengalami peningkatan sebagai bahan cemilan diberbagai restoran/ rumah makan yang ada di Sulawesi Utara.

Batang pisang goroho yang dapat dimanfaatkan sebagai bahan pakan adalah pisang bagian bawah, tengah dan atas termasuk daunnya. Batang pisang mengandung senyawa sekunder seperti tannin dan mineral (makro dan mikro). Atas dasar di atas maka telah dilaksanakan penelitian tentang penggunaan batang pisang goroho sebagai salah satu pakan penyusun ransum

\section{MATERI DAN METODE PENELITIAN}

\footnotetext{
Penelitian ini dilaksanakan dikandang Unggas Jurusan Nutrisi dan Makanan Ternak Fakultas Peternakan Universitas Sam Ratulangi Manado
}

tanggal 26 Agustus 2015 sampai tanggal 14 September 2015.

Penelitian ini menggunakan 60 ekor broiler. Kandang yang digunakan dalam penelitian adalah kandang baterey untuk fase starter (umur 3 minggu), yang dipisahkan dengan sekat-sekat sehingga membentuk ruang. Penelitian ini menggunakan 24 unit kandang dan setiap kandang ditempati 3 ekor broiler. Setiap unit kandang dilengkapi dengan tempat makan dan minum dan diberikan cahaya yang baik yaitu lampu pijar 15 watt. Kandang-kandang tersebut ditempatkan dalam ruangan dengan ventilasi dan cahaya yang cukup. Perlengkapan yang digunakan dalam penelitian ini yaitu timbangan digital untuk menimbang ransum, timbangan analog untuk menimbang broiler, kantong plastik, koran bekas, wadah tempat penyimpanan ransum perlakuan, alat tulis menulis untuk pengambilan data, ransum sisa dan lainlain.

Ransum yang digunakan dalam penelitian ini disusun dari beberapa bahan pakan,yaitu jagung kuning, tepung ikan, dedak halus, bungkil kelapa, tepung kedele, dan topmix. Selain itu, digunakan minyak kelapa untuk mencukupkan energi ransum.Kemudian batang pisang goroho di olah menjadi tepung. Komposisi zat makanan dan energi metabolis dari bahan pakan penyusun ransum dapat dilihat pada 
Tabel 1. Pada Tabel 2 disajikan komposisi bahan pakan penelitian dan Tabel 3 di sajikan komposisi zat zat makanan ransum perlakuan. Penelitian ini merupakan penelitian eksperimental dengan menggunakan Rancangan Acak Lengkap (RAL) menurut (Steel and Torie,1995) yang terdiri dari 4 perlakuan dan 5 ulangan. Respon broiler terhadap penggunaan tepung batang pisang goroho dalam ransum diukur melalui

1. Konsumsi ransum (gram) diperoleh dari selisih antara jumlah ransum yang diberikan dengan ransum sisa setiap harinya.

2. Pertambahan bobot badan (gram) yaitu diperoleh dari selisih antara bobot badan awal dengan bobot badan akhir penimbangan.

3. Konversi ransum diperoleh dari perbandingan antara pertambahan bobot badan rata-rata dari jumlah ransum yang dikonsumsi selama periode penelitian.

Tabel 1. Komposisi Zat Makanan dan energi metabolis bahan pakan Penyusun Ransum

\begin{tabular}{|c|c|c|c|c|c|c|c|}
\hline Bahan Pakan & $\begin{array}{l}\text { Protein } \\
(\%)\end{array}$ & $\begin{array}{l}\text { Lemak } \\
(\%)\end{array}$ & $\begin{array}{l}\text { Serat } \\
\text { Kasar } \\
(\%)\end{array}$ & $\begin{array}{l}\mathrm{Ca} \\
(\%)\end{array}$ & $\begin{array}{l}\mathrm{P} \\
(\%)\end{array}$ & $\begin{array}{l}\text { Abu } \\
(\%)\end{array}$ & $\begin{array}{l}\mathrm{ME} \\
\mathrm{Kkal} / \mathrm{kg}\end{array}$ \\
\hline Jagung $^{*}$ & 8,50 & 5,17 & 2,15 & 0,22 & 0,60 & 15,13 & 2983,50 \\
\hline Dedak $^{*}$ & 13,44 & 6,07 & 6,35 & 0,19 & 0,73 & 10,33 & 2695,50 \\
\hline Bungkil Kelapa* & 24,74 & 9,36 & 15,02 & 0,11 & 0,47 & 6,95 & 3279,75 \\
\hline Tepung Kedele** & 40,38 & 9,91 & 6,56 & 0,24 & 0,58 & & 2540,00 \\
\hline $\begin{array}{l}\text { Tepung Ikan** } \\
\text { Minyak * }\end{array}$ & 58,52 & $\begin{array}{l}13,90 \\
100.00\end{array}$ & 2,95 & 7,04 & 3,67 & 25,11 & $\begin{array}{l}3851,8 \\
8812\end{array}$ \\
\hline $\begin{array}{l}\text { Top Mix }{ }^{*} \\
\text { Tepung batang } \\
\text { pisang goroho }\end{array}$ & 2,53 & 1,49 & 23,48 & 5,38 & 1,44 & 12,93 & 2978,4 \\
\hline
\end{tabular}

Sumber:

*Laboratorium Kimia dan Makanan Ternak Ruminansia Fapet UNPAD ( 2013)

** Kowel (2007)

*** PT Delta (2013) 
Tabel 2. Komposisi Bahan Pakan Penyusun Ransum.

\begin{tabular}{lllll}
\hline Bahan Pakan (\%) & R0 & R1 & R2 & R3 \\
\hline Jagung & 57,00 & 54,15 & 51,30 & 48,45 \\
Tepung batang pisang goroho & 0,00 & 2,85 & 5,70 & 8,55 \\
Bungkil Kelapa & 9,00 & 9,00 & 9,00 & 9,00 \\
Tepung Kedele & 12,00 & 12,00 & 12,00 & 12,00 \\
Tepung Ikan & 15,00 & 15,00 & 15,00 & 15,00 \\
Minyak & 1,00 & 1,00 & 1,00 & 1,00 \\
Top Mix & 1,00 & 1,00 & 1,00 & 1,00 \\
\hline Total & 100,00 & 100,00 & 100,00 & 100,00 \\
\hline
\end{tabular}

Tabel 3. Komposisi Zat-Zat Makanan dan Energi Ransum Perlakuan

\begin{tabular}{lllll}
\hline & $\mathrm{R} 0$ & $\mathrm{R} 1$ & $\mathrm{R} 2$ & $\mathrm{R} 3$ \\
\hline Protein (\%) & 21,37 & 21,18 & 20,88 & 20,82 \\
Lemak (\%) & 8,37 & 8,26 & 8,16 & 8,05 \\
Serat Kasar (\%) & 4,12 & 4,73 & 5,34 & 5,96 \\
$\mathrm{Ca}(\%)$ & 1,24 & 1,23 & 1,23 & 1,22 \\
$\mathrm{P}(\%)$ & 1,03 & 1,29 & 0.99 & 0,98 \\
Abu (\%) & 13,51 & 13,44 & 13,38 & 13,32 \\
$\mathrm{ME} \mathrm{(kkal/kg)}$ & 3101,23 & 3101,08 & 3100,3 & 3100,06 \\
\hline
\end{tabular}

\section{HASIL DAN PEMBAHASAN}

Data hasil pengamatan untuk pengaruh perlakuan terhadap rataaan konsumsi ransum, pertambahan bobot badan, dan konversi ransum selama penelitian dapat dilihat pada Tabel 4.

\section{Pengaruh Perlakuan Terhadap Konsumsi Ransum}

Rataan konsumsi ransum broiler pada penelitian ini, yaitu berkisar 87,05 87,73 gram/ekor/hari. Rataan konsumsi ransum tertinggi adalah pada perlakuan yang menggunakan $10 \%$ tepung batang pisang goroho (R2) yaitu 87,73, sedangkan yang terendah pada perlakuan tanpa tepung batang pisang goroho (R0) yaitu 87,05. Rataan konsumsi ransum pada penelitian ini masih sesuai dengan yang 
Tabel 4. Rataan Konsumsi Ransum, Pertambahan Berat Badan dan Konversi Ransum.

\begin{tabular}{lllll}
\hline \multirow{2}{*}{ Parameter } & \multicolumn{3}{c}{ Perlakuan } \\
\cline { 2 - 5 } & R0 & R1 & R2 & R3 \\
\hline Konsumsi Ransum (g/ekor/hari & 87,05 & 87,55 & 87,73 & 87,15 \\
Pbb (g/ekor/hari) & $41,11^{\mathrm{a}}$ & $39,95^{\mathrm{a}}$ & $35,88^{\mathrm{b}}$ & $31,96^{\mathrm{b}}$ \\
Konversi (g/ekor/hari & $2,13^{\mathrm{a}}$ & $2,20^{\mathrm{a}}$ & $2,46^{\mathrm{b}}$ & $2,73^{\mathrm{b}}$ \\
\hline Keterangan: Superip
\end{tabular}

Keterangan: Superskip berbeda pada baris yang sama menunjukan perbedaan nyata $(\mathrm{P}<0,05)$

dinyatakan oleh Wahyu, (2004) bahwa konsumsi ransum broiler umur 1-6 minggu adalah 77-135 gr/ekor/hari.

Hasil analisis keragaman menunjukan bahwa penggunaan tepung batang pisang goroho sebagai pengganti sebagian jagung terhadap konsumsi ransum broiler memberikan pengaruh yang tidak nyata $(\mathrm{P}>0.05)$. Berarti respon broiler terhadap pemberian perlakuan tepung batang pisang goroho sama dengan perlakuan pakan kontrol (R0) atau tanpa tepung batang pisang goroho. Hal ini disebabkan karena kandungan zat-zat makanan dalam ransum perlakuan hampir sama dengan kandungan zat-zat makanan pakan kontrol, dan kandungan energi metabolis dari keempat perlakuan ransum adalah sama. Broiler mengkonsumsi ransum terutama untuk memenuhi kebutuhan energi Wahyu (2004), oleh karena kandugan energi dari keempat perlakuan ransum hampir sama maka dampak terhadap konsumsi ransum tidak berbeda nyata. Meskipun kandungan serat kasar dalam ransum terlihat ada peningkatan nilai dari R0 sampai R3, namun masih dalam batas toleransi sehingga tidak berdampak pada konsumsi ransum. Fajri (2012) menyatakan bahwa ternak unggas membutuhkan zat makanan berupa protein sebagai zat pembangun tubuh, karbohidrat dan lemak sebagai sumber energi serta vitamin dan mineral yang penting bagi perkembangan tubuh. Menurut Wahyu (2004), bahwa zat-zat makanan, kecepatan pertumbuhan dan palatabilitas juga dapat mempengaruhi konsumsi pakan.

\section{Pengaruh Perlakuan Terhadap Pertambahan Berat Badan}

Rataan pertambahan bobot badan broiler pada penelitian ini, yaitu antara 41,11 - 31,96 gram/ekor/hari (Tabel 4). Rataan bobot badan tertinggi dihasilkan oleh kelompok broiler yang mendapatkan ransum tanpa menggunakan tepung batang pisang goroho (R0) sebesar 41,11 gram/ekor/hari dan terendah terdapat pada 
perlakuan dengan $15 \%$ tepung batang pisang goroho (R3) yaitu 31.96 gram/ekor/hari. Menurut Wahyu (2004), pertambahan bobot badan broiler yang baik berkisar 35,7 - 48,6 gram/ekor/hari. Pertambahan bobot badan broiler pada perlakuan R3 dalam penelitian ini ternyata lebih rendah dari yang dinyatakan Wahyu (2004).

Hasil analisis keragaman menunjukan bahwa penggantian sebagian jagung dengan menggunakan tepung batang pisang goroho (Musa acuminata, sp) dalam ransum terhadap pertambahan berat badan broiler memberikan pengaruh yang berbeda nyata $(\mathrm{P}<0,05)$. Uji Tukey menunjukan bahwa pertambahan bobot badan $\mathrm{R}_{0}$ sama dengan $\mathrm{R}_{1}$ dan $\mathrm{R}_{2}$ sama dengan $\mathrm{R}_{3}(\mathrm{P}>0,05)$, tetapi $\mathrm{R}_{2}$ dan $\mathrm{R}_{3}$ nyata lebih rendah dari $\mathrm{R}_{0}$ dan $\mathrm{R}_{1}(\mathrm{P}<0,05)$. Adanya penurunan pertambahan bobot badan pada $\mathrm{R}_{2}$ dan $\mathrm{R}_{3}$ diduga disebabkan oleh kandungan zat anti nutrisi dalam tepung batang pisang goroho, seperti tanin dan lignin yang mempengaruhi kecernaan bahan kering dan bahan organik, (Tidi et al., 2011). Adanya kandungan zat anti nutrisi di dalam batang pisang yang mempengaruhi rasa, serta warna ransum yang diberikan (Kanazawa dan Sakakibara, 2000). Hal ini sejalan dengan Widjastuti dan Hernawan (2012) yang menyatakan bahwa bobot badan broiler menjadi menurun akibat menerima banyaknya tanin yang terkandung di dalam batang pisang. Tanin membentuk kompleks dengan protein dan mineral, yang sulit dicerna dalam saluran pencernaan sehingga menurunkan daya cerna protein sehingga menghambat pertambahan berat badan. Selain itu, didugatingginya kandungan lignin pada bahan pakan seperti pada batang pisang akan berpengaruh terhadap kerja enzim dalam mencerna zat-zat makanan. Lignin berperan memperkuat struktur dinding sel dengan mengikat selulosa dan hemiselulosa yang sulit dicerna, sehingga meskipun jumlah konsumsinya banyak namun karena tidak dapat dicerna maka tidak dapat dimanfaatkan untuk pertumbuhan ternak (Hasrida, 2011)

\section{Pengaruh Perlakuan Terhadap Konversi Ransum}

Rataan konversi ransum selama penelitian seperti terlihat pada tabel 4 yaitu antara 2,12 - 2,73. Rataan konversi ransum tertinggi diperoleh pada perlakuan dengan $15 \%$ tepung batang pisang goroho dalam ransum (R3) sebesar 2,73 dan terendah pada perlakuan tanpa tepung batang pisang dalam ransum (R0) yaitu 2,12. Nilai konversi ransum dalam penelitian ini hampir sama dengan penelitian Tumewu et al. (2015) yaitu 2,41- 3,04 serta Murib et al. (2016) yaitu $2,32-3,11$ 
Hasil analisis keragaman KESIMPULAN

menunjukan bahwa penggunaan tepung batang pisang goroho sebagai pengganti sebagian jagung memberikan pengaruh yang berbeda nyata $(\mathrm{P}<0,05)$ terhadap konversi ransum. Uji Tukey menunjukan bahwa konversi ransum $\mathrm{R}_{3}$ berbeda nyata $(\mathrm{P}<0,05)$ lebih tinggi dibandingkan dengan $\mathrm{R}_{0}$, dan $\mathrm{R}_{1}$, sedangkan antara $\mathrm{R}_{0}$ dan $\mathrm{R}_{1}$, $\mathrm{R}_{2}$ dan $\mathrm{R}_{3}$, berbeda tidak nyata $(\mathrm{P}>0,05)$, dan perlakuan antara $R_{0}$ dan $R_{2}, R_{0}$ dan $R_{3}$, $\mathrm{R}_{1}$ dengan $\mathrm{R}_{2}, \mathrm{R}_{1}$ dengan $\mathrm{R}_{3}$, menunjukan perbedaan yang nyata $(\mathrm{P}<0,05)$. Menurut Anggorodi (1985) nilai konversi ransum yang tinggi menunjukkan jumlah ransum yang dibutuhkan untuk menaikkan bobot badan semakin meningkat dan efisiensi ransum semakin rendah. Angka konversi ransum yang rendah berarti banyaknya ransum yang digunakan untuk menghasilkan satu kilo gram daging semakin sedikit, sehingga semakin baik nilai ekonomisnya, begitu pula sebaliknya. Konversi ransum pada penelitian ini sejalan dengan pertambahan bobot badan, dimana pertambahan bobot badan antara $\mathrm{R}_{0}$ dan $\mathrm{R}_{1}$ tidak berbeda nyata, tetapi lebih rendah dari $\mathrm{R}_{0}$ dan $\mathrm{R}_{1}$ demikian juga antara $\mathrm{R}_{2}$ dan $\mathrm{R}_{3}$, jadi semakin tinggi kandungan tepung batang pisang dalam ransum semakin tinggi angka konversi ransum, artinya penggunaan ransum semakin tidak efisien, hal ini disebabkan oleh tanin dan lignin.

\section{DAFTAR PUSTAKA}

Anggorodi, 1985. Ilmu Makanan Ternak Umum, Penerbit PT Gramedia Jakarta. 1985. Kemajuan Mutahkir Ternak Unggas. Universitas Indonesia Press. Jakarta.

Amrullah, I.K. 2004. Nutrisi Ayam Broiler. Lembaga Satu Gunung Budi. Bogor.

Dhalika, T., Atun Budiman, Budi Ayuningsih dan Mansyur. 2011. Nilai nutrisi batang pisang dari produk biopres (ensilage) sebagai ransum lengkap. Jurnal Ilmu Ternak 11(1): 17-23.

Djapili, D., F. Wolayan, I. Untu, H. Liwe. 2016. Pengaruh penggantian sebagian jagung dengan tepung kulit pisang raja (Musa Paradisiaca) dalam ransum terhadap performans broiler. Jurnal Zootek 36(1):158-166

Fajri, N. 2012. Pertambahan Berat Badan, Konsumsi, dan Konversi Pakan Broiler Yang Mendapat Ransum Mengandung Berbagai Level Tepung Daun Katuk (Sauropus Androginus). Tesis. Fakultas Peternakan Universitas Hasanudin Makasar.

Hagerman, A.E. and L.G. Butler. 1980. Condensed tannin purification and 
characterization of tannin-associated protein. J. Agric. Food. Chem. 28: 947-952

Hasrida. 2011. Pengaruh Dosis Urea dalam Amoniasi Batang Pisang terhadap Degradasi bahan Kering, Bahan Organik dan Protein Kasar secara In vitro. Skripsi. Fakultas Peternakan Universitas Andalas. Padang.

Kanazawa. K, dan H. Sakakibara.2000. High content of dopamine, a strong antioxidant, in cavensdish banana. J. Agric. Food Chem.48 (3): 844-848,

Kowel, Y.H.S. 2007. Pengaruh penggunaan Limbah Minyak Penggalengan Ikan dalam ransum Terhadap Efisiensi Biologis dan Kualitas Karkas Broiler. Tesis Universitas Sam Ratulangi. Program Pasca Sarjana manado

Risnajati, D. 2011. Pengaruh tingkat penambahan tepung daun singkong dalam ransum komersial terhadap performan broilerstrain CP707. Jurnal Ilmiah Ilmu-Ilmu Peternakan 14 (2): 62-67.

Santi, R. K., D. Fatmasari, S. D. Widyawati, dan W. P. S. Suprayogi. 2012. Kualitas dan nilai kecernaan In Vitro Silase batang pisang (Musa paradisiaca) dengan penambahan beberapa akselerator. Tropical Animal Husbandry Vol. 1 (1): 15-23

Steel, R, C. dan Torrie J. H. 1991.Prinsip dan Prosedur Statistika. Gramedia Pustaka Utama. Jakarta

Situmorang, N.A., L.D. Mahfuds dan U. Atmomarsono. 2013. Pengaruh pemberian tepung rumput laut (Gracilaria verrucosa)dalam ransum terhadap efisiensi penggunaan protein ayam broiler. Animal
Agricultural Journal, Vol. 2(2): 4956

Suryanto, E., L. Momuat, M. Taroreh, F. Wehantouw, N. Kojong, S. Untu, I.R. Tampa. 2010. Potensi fitokimia dari pisang goroho (Musa sapien, sp.). Prosiding. Seminar Nasional. Potensi Pangan Tradisional Dalam Rangka Peningkatan Daya Saing Nasional. Hal. 1-4

Murib, S., M. Najoan, B. Betty, I Untu. 2016. Pengaruh subtitusi dedak halus dengan tepung kulit kopi dalam ransum terhadap performa broiler. Jurnal Zootek 36(1):218- 225

Tilman, D., E.S. Reksohadiprojo, S. Prawirokusumo dan S. Lebdosoekojo, 1983. Ilmu Makanan Ternak Dasar. Fakultas Peternakan UGM. Yogjakarta.

Tumewu, C., F. N. Sompie, F.R Wolayan, Y.H.S Kowel. 2016. Pengaruh penggunaan daun murbei (Morus alba) segar sebagai pengganti sebagian ransum terhadap performans broiler. Jurnal Zootek 36(1): 33-41

Tidi, D., A. Budiman, B. Ayuningsih dan Mansyur. 2011. Nilai nutrisi batang pisang dari bioproses (Ensilase) sebagai ransum lengkap. Jurnal dua ternak Vol. 11(1): 17- 23.

Wahyu, J. 2004. Ilmu Nutrisi Unggas. Cetakan Kelima. Gadjah mada University Pres. Yogyakarta.

Widjastuti.T dan E. Hernawan. 2012. Utilizing of banana peel (Musa sapientum) in the ration and its influence on final body weight, percentage of carcass and abdominal fat on broilers under heat stress condition. Journal of Animal 
Physiologi and Animal Nutrition 83: $57-64$.

Wina, E. 2010. Tanaman pisang sebagai pakan ternak ruminansia. Jurnal Wartazoa Vol. 11 No.1.20-27.
Yamin, M. 2002. Pengaruh Tingkat Protein Pakan terhadap Konsumsi, Pertambahan Bobot Badan dan IOFC Ayam buras Umur 0-8 Minggu. Jurnal Agroland 9(3): 